\title{
The South Scandinavian barrows with well-preserved oak-log coffins
}

\author{
MadS Kähler Holst, Henrik BreUning-MadSEN \\ \& MARIANNE RASMUSSEN*
}

\begin{abstract}
Recent archaeological and pedological research on South Scandinavian Bronze Age barrows reveals that the remarkable conditions of preservation in a number of mounds are the result of particular construction techniques or special activities during construction. Augerings indicate that the phenomenon is concentrated within specific groups of barrows with central positions in a hypothetical Bronze Age communication system.
\end{abstract}

Key-words: South Scandinavia, Bronze Age, soil science, barrow construction, burial rituals

\section{Introduction}

Barrows dominate the South Scandinavian Early Bronze Age (1700-1000 BC), both in quantity of data and by research tradition. Even today after several centuries of systematic destruction of the monuments caused by intensive agriculture they are still present everywhere in the South Scandinavian landscape.

The barrows of South Scandinavia had a local basis in the Neolithic, but the marked increase which the Bronze Age saw in the intensity of barrow construction is indisputably also connected to the general accentuation and spread of barrow building within large parts of Europe at that time, represented not least by the Tumulus Culture.

The mere amount of work invested in barrow construction points to the decisive role of these monuments in the formation of South Scandinavian Early Bronze Age society and, together with the amount of available data, this justifies their central position in the research tradition. Furthermore, a small, exclusive group of finds, which attracted special attention even at an early stage of antiquarian activities in Denmark, has spurred the intense interest in the barrows of this society.

In 1823 the Royal Commission of Antiquities in Copenhagen received an account of an unusual discovery made in a Jutish Bronze Age barrow when road authorities destroyed the monument in search for building materials. In the middle of the barrow a large rust-coloured stone setting filled with water was uncovered, and on the bottom of this stone setting stood an extremely well preserved oak-log coffin (Boye 1896: 1f) (FIGURE 1).

During the following decades several similar accounts reached the antiquarian authorities in Copenhagen, and a few professional archaeological investigations of barrows with well-preserved oak-log coffins were also conducted, which led to the recovery of organic grave goods including whole costumes and preserved parts of the skin and hair. The remarkable preservation makes the oak-log coffins a unique group of burial finds within a European perspective.

At the end of the 19th century, Vilhelm Boye could present an impressive monograph on the oak-log coffins of Denmark, and where information on the composition of the mounds was available, striking similarities were revealed (Boye 1896). The outer part of the mound, the mantle, was dry and brownish in colour and without particularly well preserved organic remains. At a certain depth the excavators met an upper iron pan, which was often difficult

\footnotetext{
* Holst, Department of Prehistoric Archaeology, University of Aarhus, Moesgård, DK-8270 Højbjerg, Denmark. farkmh@moes.hum.au.dk Madsen, Institute of Geography, Copenhagen University, Øster Voldgade 10, DK-1350 København K, Denmark. hbm@server1.geogr.ku.dk Rasmussen, Historical-Archaeological Experimental Centre, Slangealleen 2, DK-4320 Lejre, Denmark. marianne.rasmussen@lejre-center.dk
}

Received 21 June 2000, accepted 11 September 2000, revised 20 November 2000. 

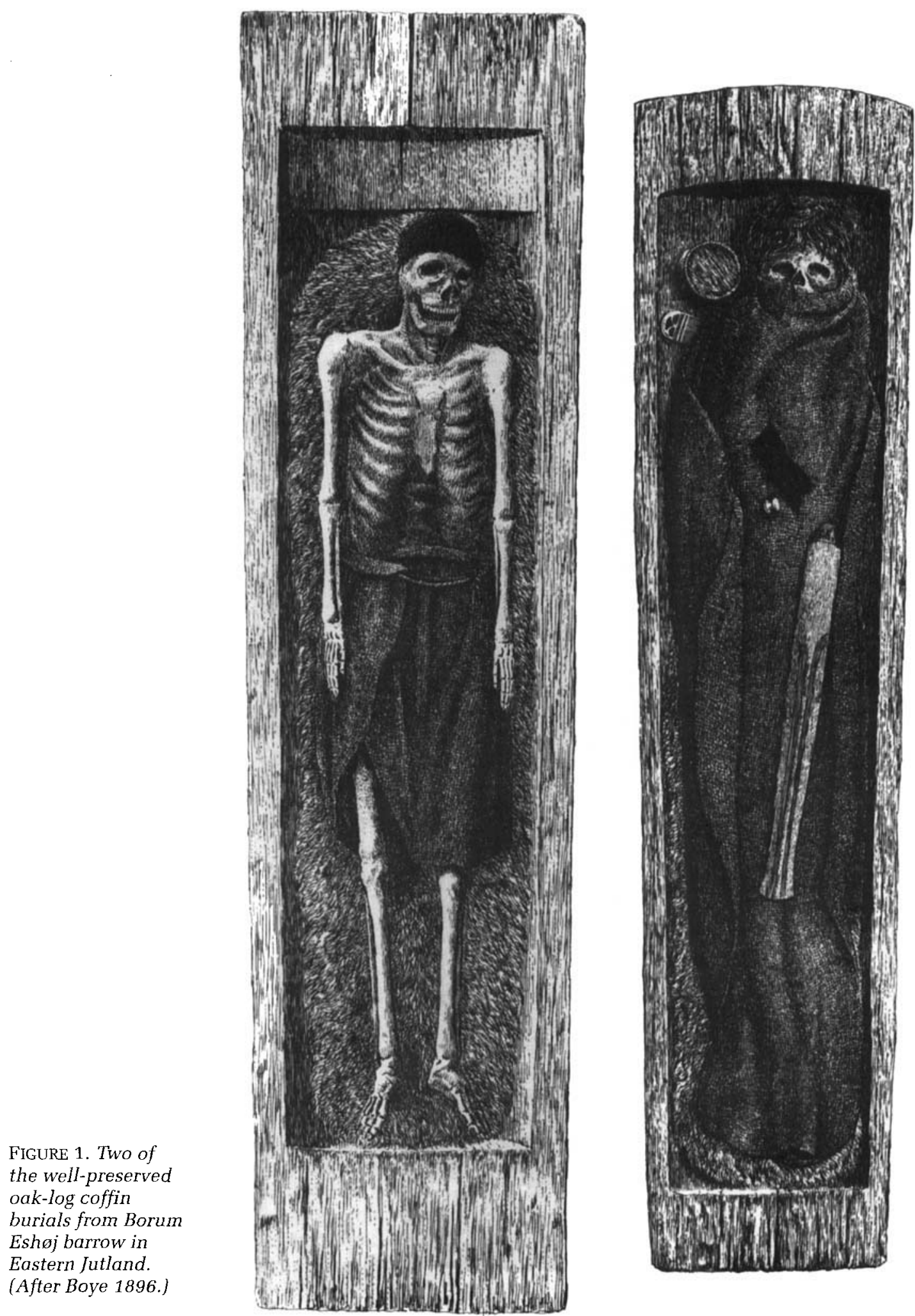

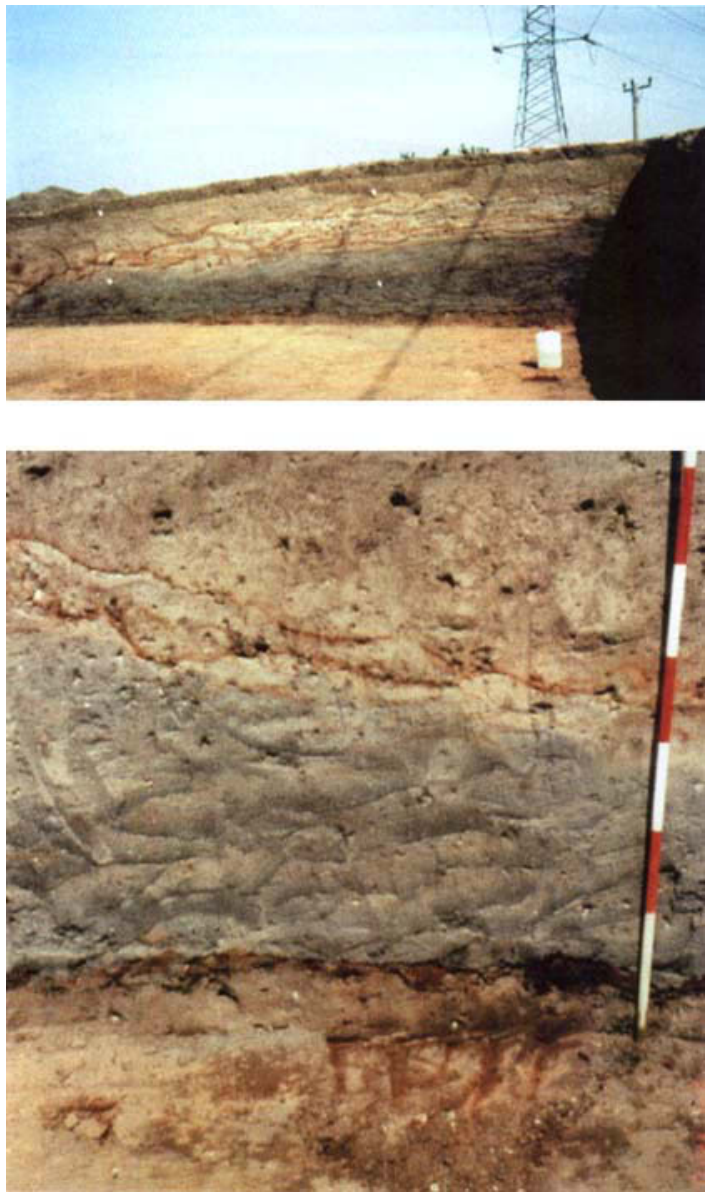

FIGURE 2. Section through the Bredhoj barrow at Lejrskov (Holst et al. 1998; Prangsgaard et al. 1999).

to break through. Beneath the upper iron pan the mound was wet, sometimes to an extreme degree causing flooding of the excavation. Bluish and grey colours characterized this wet core and the conditions of preservation were remarkably good, with clearly distinguishable plant remains on the sods of which the mound had been built. It was also here in the wet core of the mound that the well-preserved oak-log coffins were uncovered. Below the core a lower iron pan was found, and thus the core of the mound was totally encapsulated by iron pans (FIGURE 2).

Only relatively few finds of well-preserved oak-log coffins have been uncovered since Boye published his survey in 1896, but among the new discoveries are some of the most famous localities: the Egtved barrow, excavated in 1921 and containing a young woman (Thomsen 1929); and the Skrydstrup mound with another young woman, excavated in 1935 (Lund 1936; Broholm \& Hald 1939). Today approximately 30 barrows with iron-pan encapsulated mound cores and well-preserved oak-log coffin burials are known in Denmark and the present-day German province of Schleswig. Of these finds 20 contained datable artefacts, which all belong to the South Scandinavian Early Bronze Age.

Already during the excavations in the 19th century it was becoming obvious that the remarkable conditions of preservation in the oaklog coffin mounds were somehow connected to the formation of the iron pans; however, it was difficult to assess the exact nature of the connection. A number of different theories on the formation of the iron encapsulation were proposed, of which several focused on the possibility of a special mound construction being responsible for the precipitation of the iron. This raised the question whether the Bronze Age people had been aware of the preserving effects of the supposed special way of constructing the mounds (Broholm 1938).

However, in 1943 the German geologist K. Gripp proposed a theory according to which the iron pans should be seen as a purely pedological phenomenon without any connection to the mound construction. The marked differences between the core and the mantle were thought to be a secondary phenomenon which only reflected different conditions of preservation on either side of the upper iron pan and which sometimes might even have obscured archaeologically significant boundaries in the barrows (Gripp 1943).

In this way the iron pans were, from an archaeological point of view, reduced from a potential source of information on the Bronze Age burial customs and rituals to a mere nuisance in the interpretation of the excavation observations. Consequently there was no interest from archaeologists in continuing research on the formation of the iron pans. Still, due to the remarkable conditions of preservation and the resulting increased amount of information obtained through the barrows with iron pans, they remained one of the most important sources for Bronze Age burial customs and they are always referred to in studies of the graves of the period. An improved understanding of these 
monuments and their role in relation to the remaining and much more abundant barrows is thus of significant value to the study of the period.

\section{New analysis}

In recent years barrows with iron pans similar to the ones found in the barrows with wellpreserved oak-log coffins have been excavated in Jutland, unfortunately without preserved coffins. These discoveries have made it possible to revive the investigations of the formation of the iron pans and their possible connection with the construction of the barrows.

The first step in the investigations consists of a determination of which soil-forming process was responsible for the iron pan formation.

Chemical and morphological analyses have been carried out on soil samples from four newly excavated mounds and on old samples from the iron pan at Egtved Storh øj, which contained the young woman excavated in 1921 (BreuningMadsen \& Holst 1995; 1998; Holst et al. 1998; Breuning-Madsen et al. in press).

The analyses indicated that the pans have been formed by a redox-process, which is also supported by microprobe analysis of the chemical composition of the pans (Breuning-Madsen et al. 2000).

Transportation and precipitation of iron and manganese by redox-processes are typical for water-saturated soils. The water prevents air diffusion and anaerobic conditions arise. As a result, the redox-potential is lowered, and at certain values, dependent on the $\mathrm{pH}$ of the soil, iron and manganese are reduced and they become mobile. If the iron and manganese reach more aerobic areas they will precipitate and if the border between aerobic and anaerobic conditions is distinct the precipitation may occur in a narrow band forming thin, cemented iron pans as known from the barrows with well-preserved oak-log coffins.

Greyish, bluish and sometimes even greenish colours will characterize the anaerobic areas, whereas yellowish and brownish colours will characterize the aerobic areas. When compared to the profiles of the barrows it indicates that it was the cores of the mounds that were anaerobic, whereas both the subsoil below the core and the mantle above the core were aerobic, and consequently both the upper and lower iron pans were formed by transportation of iron and manganese from the core.
The formation of iron pans by redox-processes may occur within a very limited timespan of a few weeks or months. This is in agreement with the remarkable conditions of preservation in the core, which indicates that the sealing of the core happened relatively shortly after the construction of the mound.

The results of the pedological determination of the soil-forming processes in the barrows with iron-pan encapsulated core have consequences in the discussion of the possible effects of the mound construction on preservation conditions. Accordingly, the next step in the investigation of the barrows with iron pans will be an attempt to identify the consequences for our understanding of the construction sequence of these monuments based on the new knowledge of the formation of the iron pans and a reinterpretation of the archaeological excavation reports.

First of all the fact that the pans are often precipitated in a very narrow band both above and below the core indicates that there have been very distinct borders between the anaerobic conditions in the core and the aerobic conditions in the mantle and in the subsoil below the mound. This indicates that there was some structural difference or break between the mantle and the core. However, the difference does not seem to be a result of using different building materials. Both the core and the mantle in all the barrows were constructed of dry-land sods, probably from the immediate surroundings of the construction site. Nor does there seem to have been a break in the construction sequence, as the mantle is a precondition for the formation of the upper iron pan. This is also in agreement with the documentation of the sections through the more carefully examined mounds with iron pans where no continuous vegetation layer on top of the core could be observed, even though the vegetation layer of the individual sods used as building material was easily recognizable.

The distinct structural differences between the core and the mantle, the use of the same building material for both stages and the continuous construction sequence indicate that the barrows with iron-pan encapsulated cores represent a special mound construction. The pedological determination also implies that the wetness of the core of the mound to some extent must be seen as a precondition for the for- 
mation of the anaerobic conditions and the transport of the iron. Bronze Age barrows are normally situated on well-drained summits in the landscape and often on sandy soils. This makes the question of how the wetness arose central to the understanding of the formation of the iron pans. Consequently it seems probable that the difference between the core and the mantle either reflects that the core of the mound was built during a very rainy period, and that sods in the core were placed so that they somehow hindered the drainage of the water or that water was used for ritual purposes during the construction of the core.

Having set up these hypotheses on the relation between the barrow construction and the formation of the iron pans, the next step in the investigation was a testing of the hypotheses through experiments.

Two mound models approximately $6 \mathrm{~m}$ in diameter and $1.2 \mathrm{~m}$ in height were constructed at the Historical-Archaeological Experimental Centre in Lejre in 1995 and 1996. In the first mound model, the core was soaked with water during construction and when excavated three years later the core was still relatively wet. Iron coatings were found on sod surfaces in the core especially concentrated along the borders of the core and the conditions of preservation were remarkably good. In the other mound, no water was used during the construction of the core, but the sods were stacked so as to lead water towards the core and hold it there. However, no iron coatings were observed during the excavation three years later and the core was neither wet nor characterized by particularly good conditions of preservation (Breuning-Madsen et al. in press).

The experiments support the theory of the formation of the iron pans developed on the basis of the pedological research. They demonstrated that the special physical conditions observed in the real barrows, with the marked border between core and mantle, can be achieved through a special mound construction using the same building material for both core and mantle and erecting the mound in one continuous process. The experiments also stressed the significance of the water, though of course not necessarily supplied in the exact same way as in the experiment.

In conclusion, the pedological analyses and the experiments make it plausible that the well- developed iron-pan encapsulation of the cores of Bronze Age barrows could reflect specific construction principles. In this way the iron pans have again become a potential source of information on Bronze Age society and its burial customs.

\section{The archaeological record}

In the light of this new theory a renewed analysis of previous archaeological excavations can supply several arguments for the connection between iron-pan formation and mound construction. Careful examination of the way the sods were stacked and the characteristics of the sods have occasionally revealed differences between the core and the mantle. This was for instance seen in two of the analysed mounds, stressing the impression that core and mantle should be considered as two discrete constructional entities.

That the difference between core and mantle is connected to the construction and not simply a natural phenomenon is also indicated by the position of the core relative to the position of the mantle. Where the outline of the cores has been documented they are always circular, but they are often located acentrally when compared to the centre of the finished mound (e.g. Borum Eshøj (Engelhardt 1877; Boye 1896: 48ff), Guldhøj (Boye 1896: 70ff; Aner \& Kersten nr. 3820), Hüsby (Aner \& Kersten no. 2361)). This means that the wet anaerobic area has a very regular form but with a strongly varying distance from the periphery of the core to the periphery of the finished mound. This would not be the case if the border between aerobic and anaerobic conditions only reflected the natural diffusion of air in the soil.

Even though the old excavation data support the theory of the connection between the formation of the iron-pan encapsulation and either a special mound construction or activities related to the construction, they do not, however, provide any information about the exact nature of the construction principles or activities. However, it should be mentioned that layers of white sand washed down presumably by large amounts of water have been recorded on the surfaces of the cores in a few mounds (Jørgensen 1984).

The size of the cores varies considerably from small heaps of sods, only $4 \mathrm{~m}$ in diameter and $1 \mathrm{~m}$ in height, to large structures, $25 \mathrm{~m}$ in dia- 


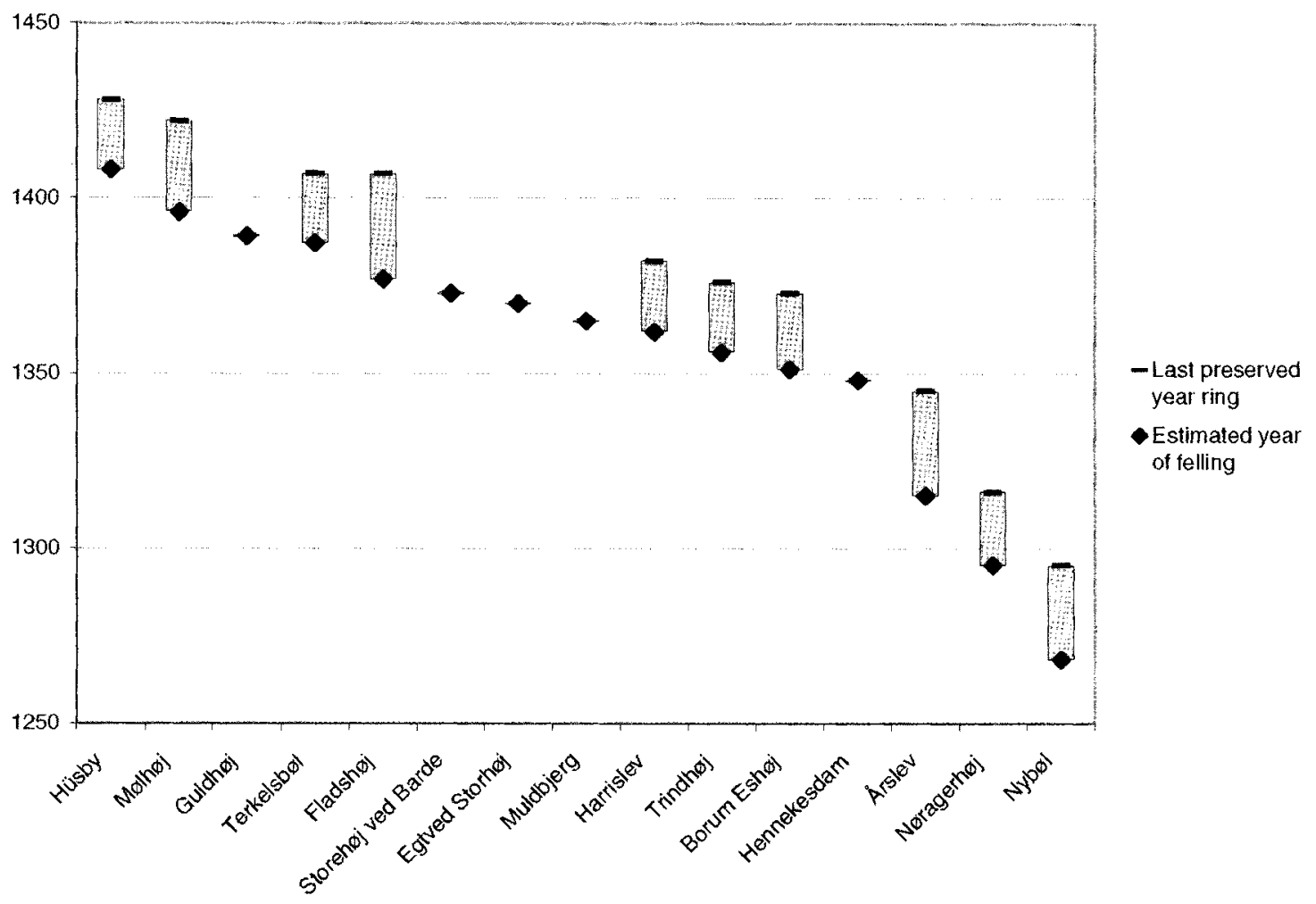

FIGURE 3. Dendrochronological dating of primary burials in barrows with iron-pan encapsulated cores.

meter and $3.5 \mathrm{~m}$ in height. Compared to other Bronze Age barrows the cores generally have a very large diameter and a relatively low height. In several cases they just barely cover the coffins. There is also some variation in the shape of the cores, but it is worth noticing that several of the cores have a large level surface. This mound form, often termed flat-mounds, is otherwise very rare within the distribution area of the well-preserved oak-log coffins (Müller 1914: 196f). The scenic platform shape together with the folkloric name 'mounds of dancing' has led to the suggestion that the flat mounds played a special role in Bronze Age ceremonial activities, but so far it has not been possible to substantiate this hypothesis in the archaeological material (Brøndsted 1939: 36). A final characteristic of the oak log coffin mounds is the relatively frequent lack of stone covers around the burials when compared to other mound burials.

The observation that the cores often just barely cover the coffins, the frequent occurrence of a special mound form, the theory that the iron-pan encapsulation of the cores reflect spe- cial activities or a special mound construction, and the conclusion of the pedological analysis that the construction of the core is quickly succeeded by the erection of the mantle, can all be seen as indications that the cores were never intended as finished mounds but only as intermediate stages, with a special function in a sequence of burial activities connected to the barrow construction.

\section{Dating}

A very interesting aspect of the archaeological evidence is the age of the barrows with wellpreserved oak-log coffins. Within recent years, 23 oak-log coffins from 18 different barrows have been dendrochronologically dated (Christensen 1998; Randsborg 1996). At 15 locations the primary burial seems to be among the dendrochronologically determined graves, so that an absolute date of the construction of the mounds is available (FIGURE 3 ).

Eleven mounds were constructed within a 50 -year period at the beginning of the 14 th century $\mathrm{BC}$, and the remaining four mounds still 
lie within a narrow time-span of approximately 150 years in the 14 th and the beginning of the 13th centuries BC. Compared to the ${ }^{14} \mathrm{C}$ datings of the Montellian periodization of the Nordic Bronze Age this corresponds to the end of period II and the very beginning of period III (Vandkilde et al. 1996). The typological dating of the artefacts in the burials also supports this dating of the oak-log coffins. Of the 20 finds determined, 16 have been placed in period II while only four belong to period III.

The dating of all excavated South Scandinavian barrows to some degree follows the same chronological pattern as the oak-log coffins with relatively few dates from period I of the Nordic Bronze Age, comprehensive material from period II and somewhat fewer dates from period III. Still the concentration within period II is clearly more marked for the oak-log coffins than for the barrows in general (Aner \& Kersten 1973).

A number of barrows with less well-developed iron pans around the core of the mound have been observed. The dating of these finds falls within a relatively broad chronological frame from period I to period V but still with a concentration in period II (Aner \& Kersten 1973; Thrane 1984).

\section{Distribution patterns}

The barrows with well-developed iron pans are so far known only from Mid and South Jutland and Slesvig. However, the less well-developed pans are in a few cases also found outside of this limited area on the islands of Funen and Zealand (FIGURE 4) (Boye 1889; Aner \& Kersten 1973; Thrane 1984). This distribution pattern may be seen as a further indication that the formation of the iron pans is culturally determined.

Another significant aspect of the spatial distribution of the barrows with iron pans is the tendency towards a concentration within a few specific groups of barrows.

Within South Scandinavia more than 100,000 barrows have been registered since the first systematic antiquarian recordings of these monuments at the end of the 19th century (The National Archaeological Record of Denmark; Aner \& Kersten 1973; Hyenstrand 1984). The barrows often occur in well-defined groups and rows, and as the location of the rows often corresponds closely to historical roads, and are oriented towards natural fords or follow navigable streams, they are thought to represent prehistoric communication lines. The concentrations or groups of mounds are traditionally considered to reflect settlement concentrations (Müller 1904).

Within some of these groups, several barrows with well-preserved oak-log coffins have been excavated. The most famous example is probably the group of 25 barrows at Vester Vamdrup in Southern Jutland, where 10 coffins were recovered from four barrows (FIGURE 5). Information about the remaining 20 mounds is very sparse and it is possible that some of the other mounds also had an iron-pan encapsulated cores (Boye 1896).

Another example, with five mounds with iron pans, is known from the South Jutland Hjordkjær group, which numbers approximately 50 mounds (FIGURE 5). Antiquarian information is available from 28 barrows within the group, but in most cases, the information was either very limited or the mounds proved to be Neolithic.

In 1998 and 1999, 100 ploughed-over barrows within Denmark were examined by augering by the authors in an attempt to localize new mounds with iron-pan encapsulated cores. Twenty-one of the examined monuments were situated in groups where previous excavations of other barrows had revealed iron-pan encapsulated cores. In six augerings, iron pans were found, though in varying degrees of development. Among the 79 barrows in groups without previously excavated iron pans, the augerings only localized two mounds with pans. This strengthened the impression that the iron pans tend to cluster within specific groups of barrows. Among the groups detected by augerings, two should be highlighted.

One is a group of 26 recorded barrows at Tobøl-Plougstrup in Southwestern Jutland (FIGURE 5). In 1999 augerings in four barrows demonstrated totally iron-pan encapsulated cores in two mounds, of which one according to antiquarian records had contained a well-preserved oak-log coffin, but the presence of the iron pans had not been documented. In addition, two other barrows within the group had yielded wellpreserved oak-log coffins in iron-pan encapsulated cores (Thrane 1963a; 1963b).

The other group worth taking into account is a group of approximately 25 mounds at Lejrskov in Southern Jutland (FIGURE 5). One 
FIGURE 4. Distribution of barrows with redox-formed iron pans. Black dots mark well-developed pans.

White dots mark weakly developed pans.

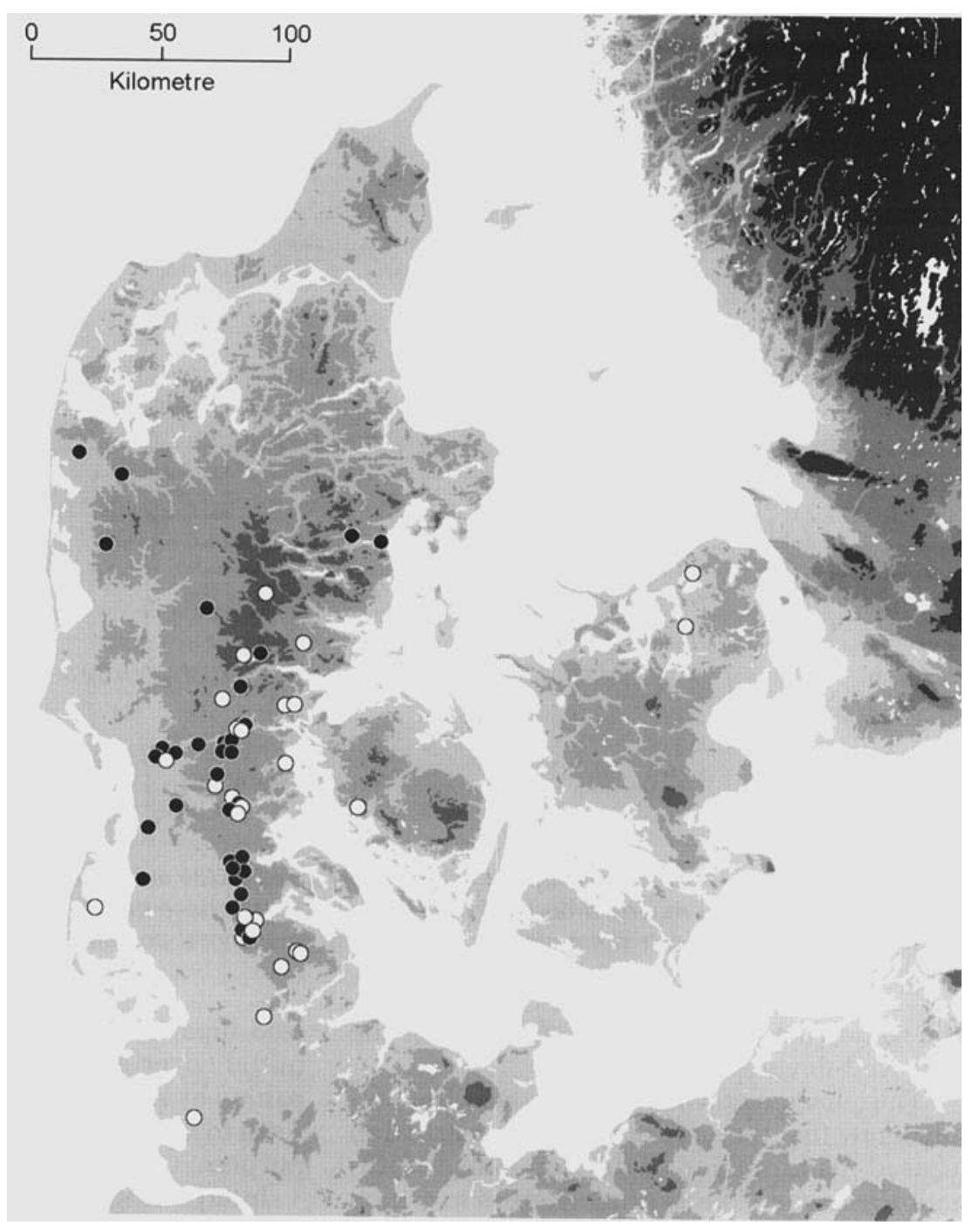

of these was excavated in 1995. It contained an iron-pan encapsulated core where the vegetation layers of the sods were still fully preserved, but unfortunately there was no coffin within the core (Holst et al. 1998; Prangsgaard et al. 1999). Augerings in 14 barrows within this group demonstrated iron pans in another three mounds.

\section{Discussion}

The pedological analysis, the experiments and the archaeological record all support the theory that the strongly developed iron-pan encapsulation of the core of a limited number of South Scandinavian barrows is the result of a common element in the principles of mound con- struction. It is at the moment not possible to determine the exact nature of this common element. However, our knowledge of the preconditions of iron-pan formation and the results of the experiments indicate that the supply of water to the core during construction is essential. It is thus possible that the anaerobic conditions are a product of a deliberate wetting of the core. This also means that the iron pans might not only reflect a special element in mound construction but also the extent to which this element was applied. This would explain the differing degrees to which the iron pans had developed as well as the discrepancy between the short time-span within which the well-developed iron pans have been dated and 


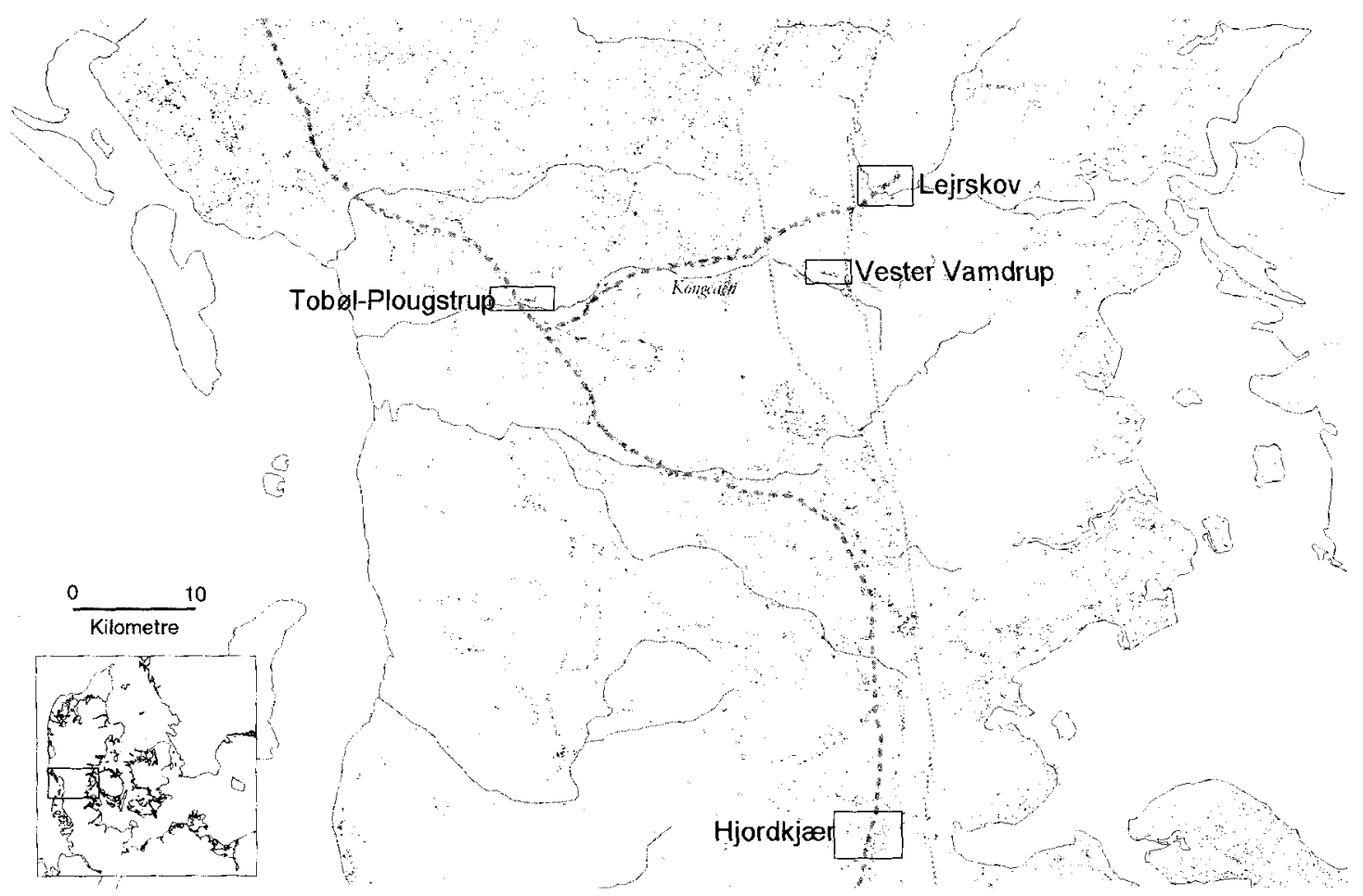

FIGURE 5. Location of the four groups of barrows discussed in the text on a backdrop of the distribution of the total number of recorded barrows in the region. Dotted lines indicate some of the major barrow routes. Solid lines indicate the major waterways, and the general position of the main Medieval transportation route through Jutland (Jorgensen 1988).

the somewhat broader frame of dating for the less well-developed pans.

The question of whether the Bronze Age people knew that the special mound construction caused the formation of the iron pans is difficult to answer. The varying degrees to which the iron pans and consequently the conditions of preservation have developed, and the fact that the iron pans after all are a relatively rare phenomenon, indicate that the wish to preserve the dead through encapsulating the mound core was either not a common part of the Bronze Age burial custom or the architects were not very successful in achieving it. At present it must be concluded that the iron pans are a natural phenomenon whose formation was advanced incidentally by a special construction technique.

With our present knowledge on the formation of the iron pans, it seems reasonable to assume that the special mound construction was ritually determined. The special construction seems to consist of a relatively standard- ized bipartite construction sequence with an initial covering of the coffin probably accompanied by special activities, and there does not seem to have been any practical constructional purpose.

Interpreting the construction of the mound as ritualized has important consequences for the understanding of the groups with several barrows containing iron-pan encapsulated cores. It highlights and qualifies the character of the close connection between the mounds within the groups, but it also implies that in the different groups there were identical rituals, which differed from mound construction activities and practices in the groups without iron pans. This indicates that the groups of barrows with iron pans may have had some special function in the Bronze Age society. With this background knowledge it is interesting to examine the geographical location of the mound groups (FIGURE 5).

If we accept that the distinct rows of barrows along the main watershed lines indicate communication lines (Müller 1904) and that 
the navigable waterways had a similar function, we see that all four identified groups with several mounds with iron pans are located at central positions in a hypothetical Bronze Age communication system. Lejrskov, Vester Vamdrup and Hjordkjær are all situated along or near the Jutish main watershed line, which throughout historic time has been the main inland transportation route in Jutland and which is marked by close concentrations of barrows along almost its entire course (Matthiesen 1934; Jørgensen 1998). The Lejrskov-group is furthermore situated at the crossing of an east-west route also marked by distinct lines of barrows. The Vester Vamdrup group is located near one of the few crossings of the Kongeå river and the Hjordkjær group is situated within an important Neolithic settlement area. Finally there is the group at Tobøl-Plougstrup. This group marks the crossing of three supposed major communication lines: the east-west route, which the Lejrskov group was also part of, a northsouth route along the west coast of Jutland and the Kongeå river, which must have been navigable far inland in the Bronze Age, and along which the Vamdrup group was also situated.

The distribution pattern might indicate that the four groups had some kind of central function in Bronze Age society, and the fact that they are all located along the same supposed communication lines makes it likely that the groups could also reflect systems of interaction. In this way, we start to see important and so far unrecorded aspects of social organization and ritual practices, and the connection between the two in the South Scandinavian Early Bronze Age. We can within a region start to reconstruct a social network where the barrows and their associated rituals were an important constituent and perhaps even the very basis of the network. Such a network could prove an extraordinary strong contextual frame for the general interpretation of the period. The iron-pan barrows offer unique opportunities of studying these rituals and identifying related entities within the network, and once again this small group of barrow in this way achieves a central position in the study of the South Scandinavian Early Bronze Age.

Acknowledgments. We wish to thank the Danish Research Councils for financing the investigations of the barrows through the research programme The Agrarian Landscape in Denmark, sub-project: The preservation of artefacts and barrows in the agrarian landscape in Denmark. We also thank the many Danish museums which have supported or contributed to the project, either during the acquisition of samples of iron pans from excavations or during the augerings in the barrows.

\section{References}

ANER, E. \& K. KERSTEN. 1973. Die Funde der älteren Bronzezeit des nordischen Kreises in Dänemark, Schleswig-Holstein und Niedersachsen. Bd. 1-10. Neumünster: Karl Wachholz Verlag.

Boye, V. 1889. Maglehøi-Fundet, Aarbøger for Nordisk Oldkyndighed og Historie 1889, 11. Række, 4. Bind: 317-40.

1896. Fund af Egekister fra Bronzealderen i Danmark. Copenhagen: A.F. Høst \& Søns Forlag.

Breuning-MadSEn, H. \& M. Holst. 1995. Genesis of iron pans in Bronze Age mounds in Denmark, Journal of Danish Archaeology 11: 80-86.

1998. Recent studies on the formation of iron pans around the oak $\log$ coffins of the Bronze Age barrows of Denmark, Journal of Archaeological Science 25: 1103-10.

BREUNING-MADSEN, H., M. HOLST \& M. RASMUSSEN. In press. The chemical environment in a barrow shortly after construction - an archaeological-pedological experiment, Journal of Archaeological Science.

BREUNING-MADSEN, H., J. RøNSBO \& M. HOLST. 2000. Comparison of the composition of ironpans in Danish barrows with bog iron and spodic material, Catena 39: 1-9.

Broholm, H. 1938: Jelsfundet. En sønderjydsk Mandsgrav fra den zldre Bronzealder, Aarboger for Nordisk Oldkyndighed og Historie 1938: 1--20.

BROHOLM, H. \& M. HALD. 1939. Skrydstrupfundet. En sønderjydsk Kvindegrav fra den Aldre Bronzealder. Copenhagen: Nordiske Fortidsminder.

BRØNOSTED, J. 1939. Danmarks Oldtid. Bronzealderen. Copenhagen: Nordisk Forlag.

Christensen, K. 1998. Tree ring dating of Bronze Age oak coffins from Denmark, in J. Jensen (ed.), Gods and heroes of the Bronze Age: 110-13. London: Thames \& Hudson.

ENGELHARDT, C. 1877. Les cercueils en chêne de Borum Æshni, Mémoires de la société royale des antiquaires du nord n.s. $1872-1877$ : 361-72.

GRIPP, K. 1943. Der Aufbau des Bronzezeitlichen Grabhügels von Harrislee, Nachrichtenblatt für Deutsche Vorzeit 1942: 90-95.

Holst, M., H. BREUNING-MADSEN \& M. OLSSON. 1998. Soil forming processes in and below a Bronze Age barrow at Lejrskov, Southern Jutland, Geografisk tidsskrift - Danish Journal of Geography 98: 46-55.

HYENSTRAND, Å. 1984. Fasta fornlämningar och arkeologiska regioner. Stockholm: Riksantikvarieämbetet och Statens Historiske Museer.

JøRGENSEN, E. 1984. To gravhøje ved Hjordkær i Sønderjylland. Om særprægede senneolitiske gravanlæg, Kuml 1984: 15589.

JØRGENSEN, M.S. 1988. Vej, vejstrøg og vejspærring. Jernalderens landfardsel, in P. Mortensen \& B.M. Rasmussen (ed.), Fra Stamme til Stat i Danmark 1: 101-16. Aarhus: Jysk Arkmologisk Selskabs Skrifter

LUND, C.M. 1936. Egekistefundt fra Skrydstrup, Fra Nationalmuseets Arbejdsmark 1936: 13-20.

MADSEN, H.B. \& I. MUNK. 1987. The influence of texture, soil depth and geology on $\mathrm{pH}$ in farmland soils. A case study from southern Denmark, Acta Agriculturæ Scandinavica $37(4)$ : 407-18. 
Matthiesen, H. 1934. Harvejen. En tusindårig Vej fro Viborg til Dannevirke. Copenhagen: Gyldendal.

MülLER, S. 1904. Vei og Bygd i Sten og Bronzealderen, Aarboger for Nordisk Oldkyndighed og Historie 1904: 1-64.

1914. Sønderjyllands Bronzealder, Aarbøger for Nordisk Oldkyndighed og Historie 1914: 195-348

National Archaeological Record of Denmark. http://www.dkc.natmus.dk

PRANGSGAARD, K., S.T. ANDERSEN, H. BRELUNing-MADSEN, M. Holst, C, Malmkos \& D. Robinson. 1999. Gravhøje ved Lejrskov, Kuml 1999: 53-97.

RANDSBORG, K. 1996. The Nordic: Bronze Age: chronological dimensions, Acta Archaeologica 67(1996): 61-9.

Thomsen, T. 1929. Egekistefundet fra Egtved fra den ældre Bronzealder. Copenhagen: Det kgl. Nordiske Oldskriftselskab.

THRANe, H. 1963a. Hjulgraven fra Storehøj ved Tobøl i Ribe Amt, Kuml 1962: 80-112.

1963b. To Egekistegrave fra Tobølegnen, Kuml 1962: 113-22. 1984. Lusehoj ved Voldtoft - en sydvestfynsk storhøj fra yngre broncealder. Odense: Odense Bys Museer.

VANDKILDE, H., U. RAHBEK \& K.L. RASMUSSEN. 1996. Radiocarbon dating and the chronology of Bronze Age southern Scandinavia, Acta Archaeologica 67(1996): 183-98. 